\title{
ANALISIS STRATEGI PEMASARAN TERHADAP TINGKAT KEPUASAN PELANGGAN OJOLALI.COM
}

\author{
S. Liawatimena ${ }^{1}$; Johan ${ }^{2}$; Selamat ${ }^{3}$
}

\begin{abstract}
The purposes of this research is to measure the customer demand in relation to the services of Ojolali.com. Therefore, it can be considered services that always met the customers demands. In this research, analysis to know the position of the Ojolali.com company and suitable strategy to conduct are also done. The results of this research gives a complete description on customer characteristic, buyer behaviour, the percentage of customer demand which is appropriate to level on Ojolali.com working performance, and the position of Ojolali.com on SWOT Matrix, and the suitable strategy, that is using opportunity to minimize the weakness.
\end{abstract}

Keywords: marketing strategy, customer satisfaction, swot analysis

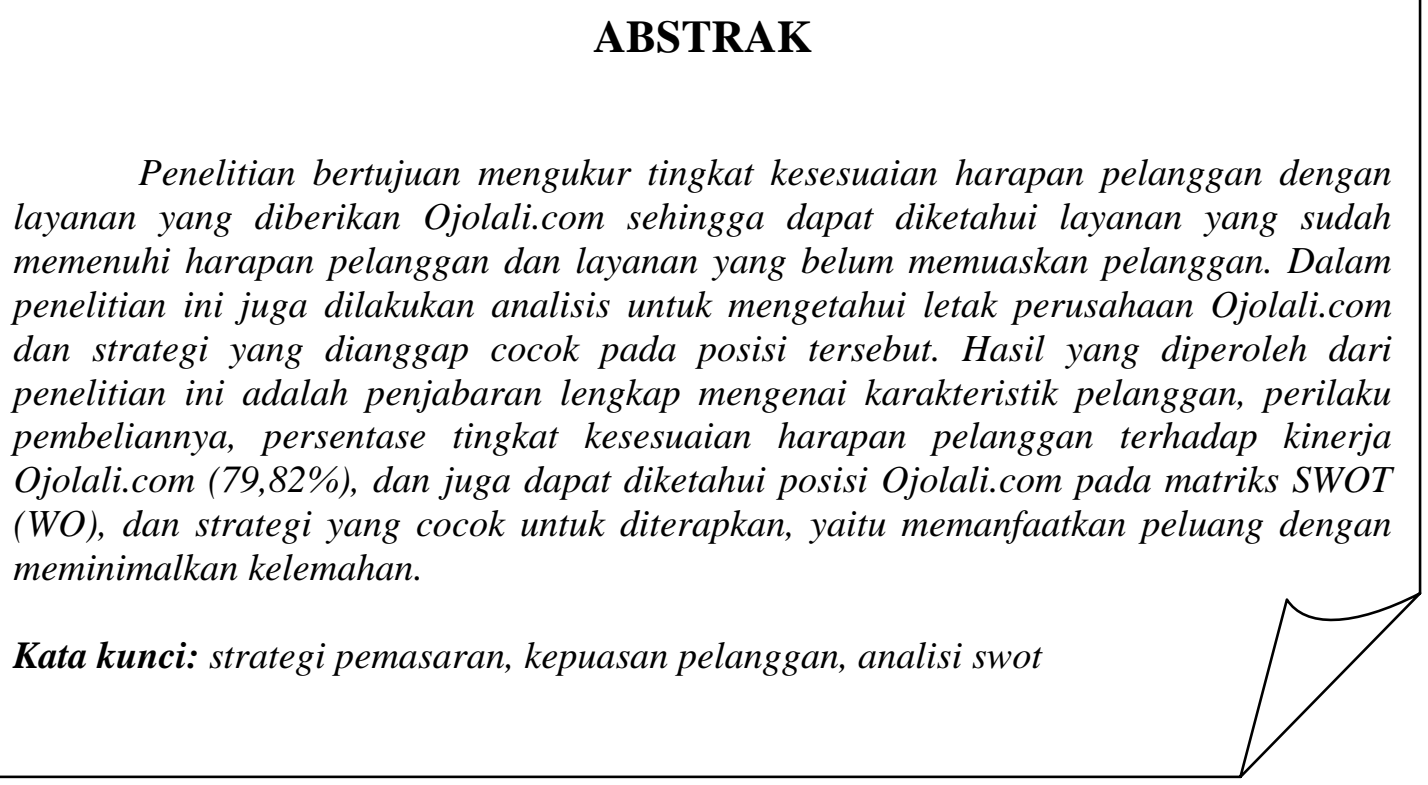

\footnotetext{
${ }^{1}$ Staf pengajar Fakultas Ilmu Komputer, UBiNus, Jakarta

2 dan 3 Mahasiswa Fakultas Ilmu Komputer, UBiNus, Jakarta
}

Ana lisis Strategi Pemasaran... (S. Liawatimena; dkk) 


\section{PENDAHULUAN}

Dunia internet yang mulai banyak diperbincangkan mulai dekade 90-an saat ini menjadi sebuah dimensi baru dalam kehidupan manusia. Kehadiran internet dalam kehidupan sehari-hari telah mengubah sebagian besar kebiasaan orang dalam berkomunikasi dengan orang lain, mulai dari sekedar menyampaikan pesan, sampai aktifitas sehari-hari seperti membaca koran, berbelanja dan lain-lain. Dengan dukungan teknologi komputer dan infrastruktur jaringan, banyak hal yang dapat dilakukan dengan internet misalnya saja berkembangnya transaksi elektronik yang disebut Electronic Commerce(E-Commerce).

Hal itu yang banyak digemari oleh pelaku bisnis untuk melakukan bisnisnya dengan cara e-Commere. Dengan adanya cara baru dalam pemasaran online, otomatis mendorong perusahaan untuk mulai memanfaatkan peluang pemasaran tersebut. Dalam melakukan e-Commerce itu, perusahaan lokal akan dituntut untuk berpikir secara lokal tetapi bertindak secara global. Dengan waktu akses berbelanja 24 jam sehari, tanpa terbatas ruang dan wilayah tertentu, mendorong perusahaan yang melakukan bisnis $e$ Commerce agar tampil semaksimal mungkin untuk memuaskan para pelangannya. Salah satu faktor yang disukai oleh perusahaan dalam melakukan bisnis online itu adalah tidak diperlukannya bangunan atau areal untuk memajang barang dagangan mereka karena bisnis online (e-Commerce) itu hanya memerlukan sebuah situs yang biasanya dalam bisnis konvensional dapat diibaratkan seperti sebuah toko.

Di Indonesia, sudah banyak sekali berdiri perusahaan atau organisasi yang melakukan transaksi secara elektronik seperti itu, salah satunya adalah Ojolali.com. Ojolali.com melakukan e-Commerce dengan situsnya www.Ojolali.com. Situs itu menawarkan berbagai jenis produk, baik lokal maupun produk impor. Untuk kemudahan mencari, Ojolali.com membagi produk tersebut ke dalam beberapa kategori, contoh Books, music, flowers, health, gifts, elektronik, dan lain lain. Dalam dunia e-Commerce, bukan hanya pembelian tunai saja yang ditawarkan. Sama seperti dalam bisnis konvensional, bisnis e-Commerce juga menawarkan pembayaran dengan cara kredit.. Ojolali.com pun mencoba menerapkan hal tersebut, yaitu pembayaran dengan cara kredit untuk produk tertentu.

Dalam menjalankan usaha e-Commerce, perusahaan Ojolali.com merasa adanya ketidakseimbangan antara member yang mendaftar dengan jumlah member yang melakukan transaksi pembelian. Oleh karena itu, Ojolali.com ingin mengetahui sejauh mana tingkat kesesuaian antara kinerja yang diberikan perusahaan terhadap harapan para pelanggan. Dengan mencari tahu sejauh mana tingkat kepuasan pelanggan yang menggunakan transaksi e-Commerce, diharapkan dapat memberi masukan kepada 
perusahaan agar dapat melihat sejauh mana strategi pemasaran yang telah diterapkan dan bagaimana membuat strategi pemasaran yang lebih efektif untuk meningkatkan pendapatan perusahaan.

Untuk melakukan analisis terhadap strategi pemasaran dan tingkat kepuasan pelanggan, dalam penelitian ini dibatasi pada penerapan strategi pemasaran perusahaan dan pengukuran tingkat kepuasan pelanggan dengan perancangan kuesioner. Agar lebih terarah pada tujuan penelitian dan pembahasan, hanya dibahas hal berikut.

1. Apakah kinerja yang diberikan Ojolali sudah sesuai dengan harapan pelanggan?

2. Strategi pemasaran yang dianggap cocok untuk diterapkan oleh Ojolali.com sebagai perusahaan yang berbasis eCommerce?

Dalam penelitian ini, penulis mencoba untuk mengetahui lebih mendalam mengenai stretegi pemasaran ojolali.com dan tingkat kepuasan pelanggan Ojolali.com. Tujuan penelitian sebagai berikut.

1. Menganalisis tingkat kesesuaian antara harapan pelanggan dengan tingkat kinerja perusahaan.

2. Menganalisis strategi yang cocok untuk di terapkan oleh Ojolali.com.

Manfaat penelitian adalah agar dapat memberikan masukan kepada perusahaan berupa tindakan yang harus dilakukan untuk meningkatkan efektifitas pemasaran.

\section{Pengertian Internet}

Menurut Sutedjo (2001:10), Internet (International Network) adalah sebuah jaringan komputer yang sangat besar yang terdiri dari jaringan kecil yang saling terhubung menjangkau seluruh dunia.

\section{Pengertian e-Commerce}

Menurut Baum (Purbo, 2001:2), e-Commerce merupakan satu set dinamis teknologi, aplikasi, dan proses bisnis yang menghubungkan perusahaan, konsumen, dan komunitas tertentu melalui transaksi elektronik dan perdagangan barang, pelayanan, dan informasi yang dilakukan secara elektronik.

\section{Mekanisme e-Commerce dalam Dunia Bisnis}

Menurut Kosiur (Indrajit, 2001:6), e-Commerce melibatkan teknologi komputer dan telekomunikasi secara intensif sebagai sarana untuk melakukan dua hal utama berikut.

1. Mengolah data mentah menjadi informasi yang dapat dimanfaatkan bersama oleh para pelaku bisnis dan konsumen. 
2. Mendistribusikan data atau informasi tersebut secara cepat dan efisien ke seluruh komponen bisnis yang membutuhkan.

Menurut Indrajit (2001:7), dari beragam jenis aplikasi e-Commerce yang ada, secara prinsip mekanisme kerjanya kurang lebih sama, seperti yang terlihat pada Gambar 1 berikut ini.

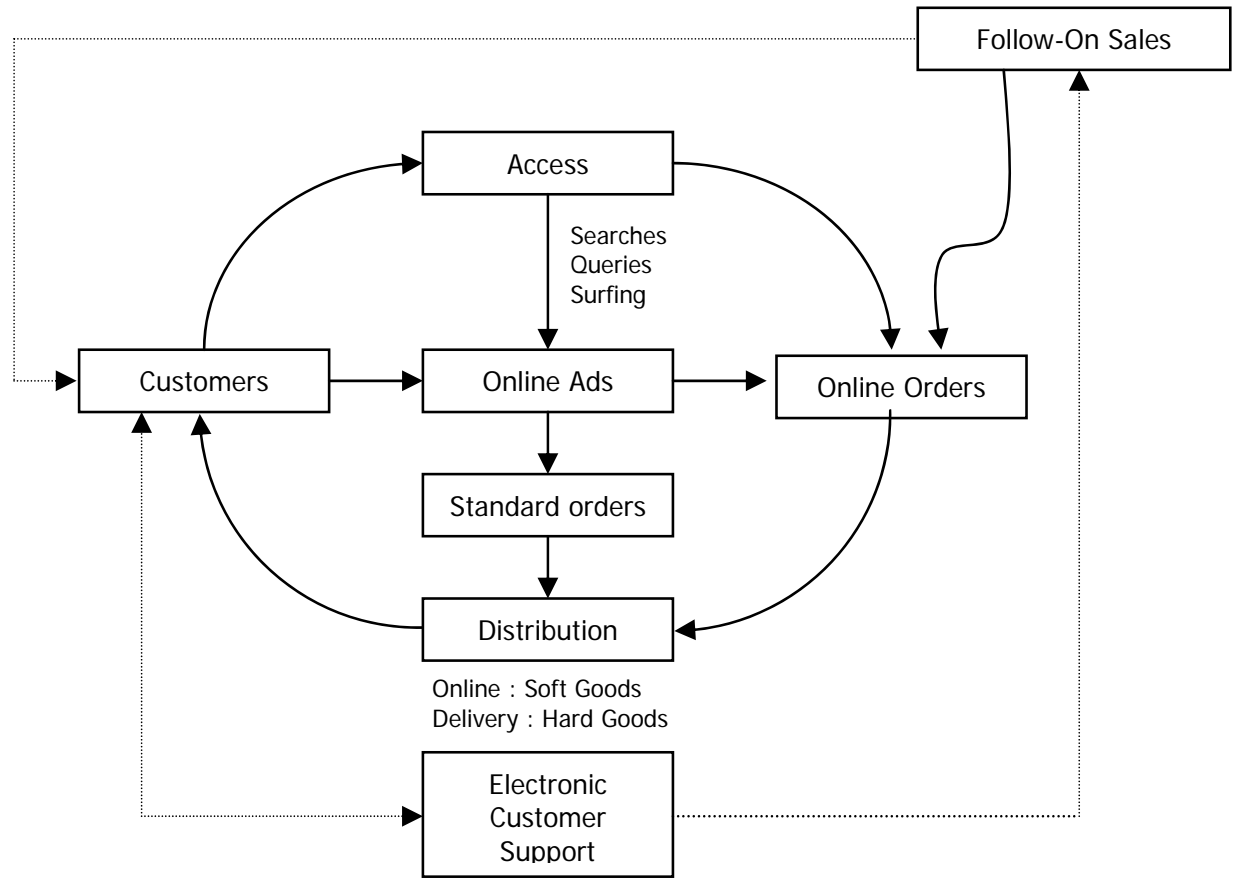

Gambar 1 Mekanisme e-Commerce

\section{Kepuasan Pelanggan}

Menurut Oliver (dalam Supranto, 2000:168-171), kepuasan adalah tingkat perasaan seseorang setelah membandingkan kinerja/hasil yang dirasakan dengan harapannya. Jadi, tingkat kepuasan merupakan fungsi perbedaan antara kinerja yang dirasakan dengan harapan. Apabila kinerja dibawah harapan maka pelanggan akan kecewa, bila kinerja sesuai dengan harapan maka pelanggan akan puas. Begitu juga apabila kinerja melebihi harapan maka pelanggan akan sangat puas.

Hanson (2000:168-171) mempertimbangkan empat fundamental yang esensial dalam menciptakan kepuasan pelanggan (lihat Gambar 2). Masing-masing menampilkan produk atau proses suatu perusahaan berinteraksi dengan pelanggan dan memberikan 
bingkai bermanfaat untuk memahami bagaimana jaringan (Net) dapat meningkatkan kepuasan pelanggan.

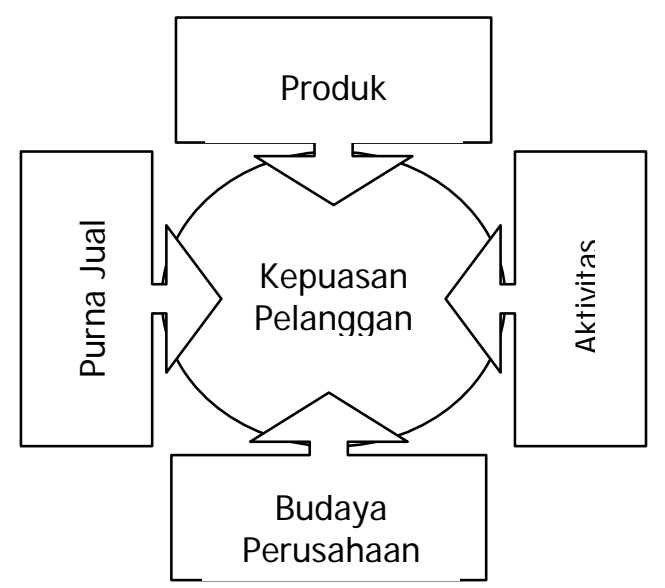

Gambar 2 Arah Kepuasan Pelanggan

\section{Jenis dan Metode Penelitian}

Dalam penelitian ini, metode yang dipergunakan adalah riset deskriptif sesuai dengan tujuan penelitian untuk menguraikan sifat suatu keadaan. Riset deskriptif bertujuan untuk menghasilkan informasi yang digunakan untuk memberikan gambaran secara umum mengenai sikap, pendapat, dan persepsi yang diberikan pelanggan terhadap kinerja pelayanan yang diberikan oleh perusahaan.

\section{Definisi Operasional}

Definisi operasional yang digunakan dalam penelitian ini sebagai berikut.

\section{Pelanggan}

Semua orang yang menuntut perusahaan untuk memenuhi suatu standar kualitas tertentu dan karena itu akan memberikan pengaruh pada performasi (performance) perusahaan.

2. Layanan Pelanggan (customer Service)

Layanan pelanggan adalah aktivitas yang didesain oleh perusahaan dengan tujuan untuk meningkatkan kepuasan pelanggan baik sebelum, selama, bahkan setelah pembelian.

3. Kepuasan Pelanggan 
Suatu tingkatan yang perkiraan kinerja produkny sesuai dengan harapan pembeli. Dengan kata lain, kepuasan pelanggan tercipta apabila kinerja/pelayanan yang diberikan oleh Ojolali.com sesuai dengan harapan pelanggannya.

\section{Variabel dan Indikator Penelitian}

Tabel 1 Variabel dan Indikator Penelitian

\begin{tabular}{ll}
\hline Variabel & Indikator \\
\hline Data Pelanggan & Jenis Kelamin \\
& Usia \\
& Tempat Tinggal \\
& Pekerjaan \\
& Pengeluaran per Bulan \\
\hline Aktifitas Pelanggan & Sumber Mengetahui Informasi \\
& Jenis Produk yang Dicari \\
& Alasan Berbelanja \\
& Frekuensi Pembelian \\
\hline Kinerja Perusahaan & Tampilan Website \\
& Pembagian kategori Produk \\
& Kelengkapan Produk \\
& Kelengkapan Informasi Produk \\
& Harga yang Kompetitif \\
& Layanan Offline \\
& Kemudahan Proses Transaksi \\
& Keamanan Transaksi \\
& Keamanan Data Pelanggan \\
& Kecepatan Pengiriman Barang \\
& Ketepatan Pengiriman Barang \\
& Respon Tehadap Keluhan dan Saran \\
& Kesesuaian Produk yang Dipesan \\
& \\
\hline
\end{tabular}

\section{Teknik Analisis Data}

Skala Likert adalah suatu alat atau metode untuk mengukur sikap, pendapat, dan persepsi responden terhadap suatu obyek yang sedang diteliti. Setelah data dikelompokkan dengan teknik pembobotan (rating). Hasil pengumpulan data dengan skala Likert itu diolah lebih lanjut dengan perhitungan dan diposisikan pada diagram kartesius. Skala yang digunakan dalam penelitian ini adalah skala 4 tingkat (sangat penting, penting, cukup penting, dan tidak penting). Hal itu dimaksudkan agar data yang 
didapat menunjukkan kecenderungan yang jelas, tidak ditengah-tengah. Untuk tingkat harapan pelanggan, diberikan bobot sebagai berikut.

1. Jawaban penting diberi bobot 4, berarti pelanggan puas.

2. Jawaban cukup penting diberi bobot 3 , berarti pelanggan cukup puas.

3. Jawaban kurang penting diberi bobot 2, berarti pelanggan cukup puas.

4. Jawaban tidak penting diberi bobot 1 , berarti pelanggan tidak puas. berikut.

Untuk kinerja atau pengalaman, diberikan penilaian dengan bobot sebagai

1. Jawaban sangat baik diberi bobot 4, berarti pelanggan sangat puas.

2. Jawaban baik diberi bobot 3 , berarti pelanggan puas.

3. Jawaban tidak baik diberi bobot 2, berarti pelanggan tidak puas.

4. Jawaban sangat tidak baik diberi bobot 1 , berarti pelanggan sangat tidak puas.

Dalam penelitian ini. terdapat 2 buah variabel yang diwakilkan oleh huruf $\mathrm{X}$ dan $Y$. "X” merupakan tingkat kinerja perusahaan yang dapat memberikan kepuasan para pelanggan sedangkan "Y" merupakan tingkat harapan pelaggan. Tingkat kesesuaian adalah hasil perbandingan skor kinerja dengan skor harapan. Tingkat kesesuaian itulah yang akan menentukan urutan prioritas peningkatan faktor yang akan mempengaruhi kepuasan pelanggan.

Rumus yang digunakan sebagai berikut.

$$
\begin{aligned}
& \mathrm{Tki}= \frac{\mathrm{Xi}}{\mathrm{Yi}} * 100 \% \\
& \mathrm{Tki}=\text { Tingkat Kesesuaian Responden } \\
& \mathrm{Xi}=\text { Skor Penilaian Kinerja Perusahaan } \\
& \mathrm{Yi}=\text { Skor Penilaian Harapan Pelanggan }
\end{aligned}
$$

Selanjutnya, sumbu mendatar (X) akan diisi oleh skor tingkat pelaksanaan sedangakan sumbu diisi oleh skor tingkat Harapan.

\section{Gambaran Umum Perusahaan}

\section{Sejarah Perusahaan}

Pada awalnya adalah ide tentang bagaimana menyediakan kebutuhan produk dan layanan untuk mengungkapkan perhatian dan kepedulian kepada orang-orang di sekeliling lingkungan. Terbentuklah Ojolali.com, ungkapan yang berasal dari bahasa Jawa yang berarti “Jangan Lupa”. Situs Ojolali.com telah memulai operasinya sejak bulan Desember 1999 dan diluncurkan secara resmi pada tanggal 31 Maret 2000. Ojolali.com dikembangkan serta dikelola secara teknis oleh PT Plexis Erakarsa Pirantiniaga (Plasmedia), perusahaan pengembangan solusi teknologi informasi yang berdiri sejak tahun 1998 dan berkantor di Jakarta. 
Desain Ojolali.com mengalami 3 kali perubahan secara signifikan. Perubahan pertama pada September 2000 ketika terjadi penambahan produk dan pada Oktober 2001, Ojolali.com dibuat sedemikian rupa untuk penyegaran, penambahan produk, dan akses yang lebih cepat. Ojolali.com akan mengembangkan berbagai layanan baru, terutama ke arah pasar korporasi.

\section{Perkembangan Perusahaan}

1. Tahap pertama atau disebut "ojolali I“ adalah permulaan berdirinya situs berbelanja itu dengan menawarkan dua kategori yang saat itu telah terbukti kompabilitasnya dengan dunia internet, yaitu bunga dan kado/hadiah (flower and gifts). Pada tahap itu juga, setelah peredaran di dalam lingkungan kecil relasi dan kerabat Ojolali.com, situs itu mulai diluncurkan ke pasar umum dengan diadakannya event besar-besaran berupa Grand Launching.

2. Melihat banyaknya permintaan dari konsumen, baik di dalam maupun di luar negeri, untuk diadakannya transaksi menggunakan kartu kredit maka situs Ojolali.com melakukan kerja sama strategis dengan salah satu penyedia jasa pembayaran online terbesar di Indonesia dengan reputasi ternama yang secara tepat bernama Cipas.co.id. Kerja sama itu memungkinkan konsumen Ojolali.com untuk membebankan transaksi mereka pada tiga kartu kredit, yaitu Visa, Mastercard, dan American Express(Amex) dengan perantara pihak ketiga yang terspesialisasi, yaitu Cipas.co.id. Tahap ekspansi produk dan kerja sama strategis itu dinominasikan dengan nama "Ojolali II“.

3. Seiring dengan kemajuan yang dialami Ojolali.com, selanjutnya dilakukan ekspansi ke dalam kategori yang merupakan "akar" bertumbuhnya transaksi online, yaitu kategori buku. Guna mendapatkan supplier yang terpercaya dan terjamin kualitasnya, Ojolali.com berhasil menggandeng divisi online dari salah satu penerbit ternama di Indonesia, yaitu PT Gramedia, melalui kerja samanya dengan Telemedia. Kerja sama itu menandakan dimulainya tahap yang sedang dijalani Ojolali.com sampai saat ini, yaitu "Ojolali III“. Dalam tahap itu juga, telah ditambahkan kategori elektronik yang mencakup subkategori Telephones (Mobile, Cordless, Fixed, Fax) serta Entertaiment (TV, Audio dan Video, Mini Hi-Fi, Portables, Digital camera).

\section{PEMBAHASAN}

\section{Analisis Perilaku pelanggan}

\section{Karakteristik Responden}

Responden yang diteliti berjumlah 50 orang, terdiri dari 34 orang pria (68\%) dan 16 orang wanita (32\%). Hal itu menunjukkan bahwa ada perbedaan yang cukup menonjol antara pria dan wanita (selisih 36\%) dalam melakukan kegiatan berbelanja online. 
Dari hasil survei tentang usia, dapat diketahui bahwa tidak ada pelanggan yang berusia di bawah 20 tahun, mayoritas pelanggan Ojolali.com adalah kelompok usia 31-40 tahun, yaitu sebanyak 54\%. Kelompok mayoritas kedua adalah kelompok umur 21-30 tahun sebanyak 40\% kemudian diikuti kelompok minoritas, yaitu kelompok usia 41-50 tahun, yaitu sebanyak $6 \%$.

Hasil survei tersebut menunjukkan bahwa tidak ada responden yang berasal dari kelompok berusia di bawah 20 tahun dan kelompok di atas 50 tahun. Hal itu mungkin disebabkan oleh kurangnya pengetahuan tentang teknologi internet dan juga mungkin karena kurangnya rasa kurang peraya pada konsep belanja di internet. Berbeda dengan kelompok usia 21-30 tahun dan kelompok usia 31-40 tahun dan mungkin kelompok itu sudah memiliki pengetahuan, kepercayaan, dan kematangan dalam mengambil keputusan.

Survei mengenai tempat tinggal responden dalam penelitian ini dikelompokkan menjadi empat, yaitu Jabotabek, Jawa-Bali, luar jawa, luar negeri. Hasil survei menunjukkan bahwa sebagian responden berasal dari Jabotabek (Jakarta, Bogor, Tangerang, Bekasi), yaitu sebesar $48 \%$ dari total responden, terbanyak kedua berasal dari daerah Jawa sampai Bali, meliputi Bandung, Yogyakarta, Surabaya, dan kota besar di Jawa dan Bali, yaitu sebesar 36\%. Responden yang berasal dari luar pulau Jawa tampaknya sangat sedikit, yaitu sebesar $12 \%$ ditambah lagi responden yang berdomisili di luar negeri dengan kelompok paling sedikit, yaitu sebesar 4\%. Hal itu mungkin menunjukkan bahwa tingkat kepercayaan luar negeri terhadap situs online di Indonesia masih kurang.

Dari Hasil survei tentang pekerjaan responden, dapat dilihat bahwa sebesar 36\% pelanggan Ojolali.com adalah karyawan swasta, diikuti dengan mahasiswa sebagai mayoritas kedua sebesar $24 \%$, kemudian para profesional sebesar $20 \%$, para wiraswasta $12 \%$, serta pegawai negeri sebanyak $8 \%$.

Pelanggan Ojolali.com dapat dikatakan sebagian besar adalah orang-orang yang sudah berpenghasilan cukup besar. Terlihat pada Tabel 5 dan sebesar $44 \%$ pelanggan Ojolali.com adalah orang-orang yang mempunyai pengeluaran di atas Rp5.000.000,00/bulan kemudian sebesar 36\% lainnya mempunyai pengeluaran Rp2.000.000,00 - Rp5.000.000,00/bulan, dan sebanyak 20\% mempunyai pengeluaran Rp1.000.000,00 - Rp2.000.000,00/bulan.

\section{Perilaku Pelanggan}

Pelanggan Ojolali.com ternyata mendapatkan informasi dari berbagai sumber. Pada penelitian ini, sumber informasi dikelompokkan menjadi 4 kategori, yaitu melalui iklan di internet, surat kabar, teman, atau keluarga dan sumber lainnya. 
Berdasarkan hasil survei dapat dikatakan bahwa iklan di internet sangat efektif bagi perusahaan untuk mempromosikan situsnya. Hal itu karena lebih dari separuh (56\%) pelanggan mengenal Ojolali.com dari iklan di internet sedangkan penyebaran informasi dari teman atau keluarga juga cukup efektif, yaitu sebesar 34\% pelanggan mengenal Ojolali.com dari teman atau keluarganya. Oleh karena itu, kepuasan pelanggan sangat perlu diperhatikan sehingga apabila seorang pelanggan merasa puas maka ia akan menceritakan kepada teman dan saudaranya.

Menurut hasil survei, sebanyak $48 \%$ atau hampir setengah dari pelanggan Ojolali.com memanfaatkan situs itu untuk membeli hadiah atau bingkisan, dan persentase untuk membeli buku menduduki posisi kedua, yaitu 28\%, dah membeli barang lainya sebesar $16 \%$. Untuk membeli barang elektronik dengan online, kurang begitu digemari (8\%). Hal itu karena umumnya orang-orang membeli barang elektronik harus melihat bentuk fisik barang tersebut sehingga menimbulkan kepercayaan terhadap barang tersebut, berbeda dengan hanya melihat gambarnya.

Dalam bertransaksi, keamanan yang terjamin adalah faktor paling utama untuk menarik minat pembeli. Hal itu dapat dilihat dalam Tabel 9 berikut ini, yaitu 28 orang dari 50 orang (56\%) pelanggan memilih berbelanja di Ojolali.com karena adanya Jaminan Keamanan. Faktor yang tidak kalah penting adalah kelengkapan produk. Sebesar 24\% pelanggan memilih alasan tersebut untuk berbelanja di Ojolali.com. Proses yang cepat mendapat presentase sebesar 12\% dan 8\% lainnya memiliki alasan lainnya.

Mengenai transaksi yang pernah dilakukan di Ojolali.com sampai saat ini, survei menunjukkan bahwa para pelanggan Ojolali.com kebanyakan melakukan transaksi antara 1-5 kali sebanyak 44\% dan 6-10 kali sebanyak 36\%, dan untuk jumlah transaksi antara 11 - 15 kali pelanggan Ojolali hanya mempunyai presentase sebesar 14\%. Untuk transaksi $>15 \%$, hanya ada $6 \%$ pelanggan dari 50 orang pelanggan yang telah melakukannya.

\section{Analisis Kesesuaian Responden}

Sesuai dengan konsep dasar bahwa seorang pelanggan akan puas apabila kinerja perusahaan semakin mendekati harapan pelanggan maka analisis yang digunakan dalam penelitian ini adalah analisis yang mengupas dan mengolah data tentang tingkat kinerja dan harapan pelanggan. Metode yang digunakan adalah metode penghitungan tingkat kesesuaian responden dan metode rata-rata. Sebelum diolah, data setiap faktor terlebih dahulu dimasukkan ke dalam suatu tabel frekuensi harapan dan pengalaman kemudian dikelompokan berdasarkan faktor, faktor pertama adalah tampilan website.

Berdasarkan hasil survei, dari segi tampilan website, dapat diketahui bahwa kesesuaian responden terhadap faktor itu adalah sebesar 80,90\%.

Dari segi pengelompokan kategori produk, dapat diketahui bahwa kesesuaian responden terhadap faktor itu adalah $84,77 \%$. 
Dari segi kelengkapan produk, dapat diketahui bahwa kesesuaian responden terhadap faktor itu adalah sebesar 82,74\%.

Dari segi kelengkapan informasi produk, dapat diketahui bahwa kesesuaian responden terhadap faktor itu adalah sebesar $85,00 \%$.

Dari segi harga yang kompetitif, dapat diketahui bahwa kesesuaian responden terhadap faktor itu adalah sebesar 68,50\%.

Dari faktor layanan offline melalui telepon, diketahui bahwa tingkat kesesuaian responden terhadap faktor itu adalah sebesar $71,42 \%$.

Dari segi kemudahan proses transaksi, dapat diketahui bahwa tingkat kesesuaian responden terhadap faktor itu adalah sebesar $82,50 \%$.

Dari segi tingkat kesesuaian responden, dapat diketahui bahwa kesesuaian responden terhadap faktor itu adalah sebesar $87,00 \%$.

Dari segi keamanan data pelanggan, dapat diketahui bahwa tingkat kesesuian responden terhadap faktor itu adalah sebesar 79,50\%.

Dari segi kecepatan pengiriman barang, dapat diketahui bahwa kesesuaian responden terhadap faktor itu adalah sebesar $82,50 \%$.

Dari ketepatan pengiriman barang, dapat diketahui bahwa tingkat kesesuian responden terhadap faktor itu adalah sebesar 78,00\%.

Dari segi respons terhadap keluhan dan saran, dapat diketahui bahwa kesesuaian responden terhadap faktor itu adalah sebesar 78,50\%.

Dari segi kesesuaian produk yang di pesan, dapat diketahui bahwa tingkat kesesuian responden terhadap faktor itu adalah sebesar $81,50 \%$.

\section{Hasil Diagram Kartesius}

Setelah data dikumpulkan dan diklasifikasikan ke dalam masing-masing faktor dan diberi bobot, data tersebut dirangkum ke dalam satu tabel yang terdiri dari 2 variabel $(\mathrm{X}, \mathrm{Y})$. Variabel $\mathrm{X}$ diwakilkan oleh kinerja dan variabel $\mathrm{Y}$ diwakilkan oleh tingkat harapan responden. Setelah data dimasukan kemudian dicari rata-rata X dan Y, variabel $\mathrm{X}$ dan $\mathrm{Y}$ yang telah dirata-rata tadi dirata-ratakan lagi. Setelah didapat koordinat titik untuk masing-masing faktor maka titik-titik tersebut diposisikan ke dalam suatu diagram yang terdiri dari empat kuadran, yaitu Diagram Kartesius. 
Tabel 24 Perhitungan Rata-Rata Penilaian Kinerja dan Penilaian Harapan pada Faktor yang Mempengaruhi Kepuasan Pelanggan Ojolali.com

\begin{tabular}{|c|c|c|c|c|c|}
\hline No. & $\begin{array}{c}\text { Faktor yang Mempengaruhi Kepuasan } \\
\text { Pelanggan Ojolali.com } \\
\end{array}$ & $\begin{array}{c}\text { Penilaian } \\
\text { Pengalaman }(\mathrm{X})\end{array}$ & $\begin{array}{c}\text { Penilaian } \\
\text { Harapan (Y) }\end{array}$ & X & Y \\
\hline 1 & Tampilan website yang menarik & 161 & 199 & 3,22 & 3,98 \\
\hline 2 & Pengelompkan kategori produk & 167 & 197 & 3,34 & 3,94 \\
\hline 3 & Kelengkapan produk & 163 & 200 & 3,26 & 4,00 \\
\hline 4 & Kelengkapan informasi produk & 170 & 200 & 3,40 & 4,00 \\
\hline 5 & Harga yang kompetitif & 137 & 200 & 2,74 & 4,00 \\
\hline 6 & Layanan Offline & 140 & 196 & 2,80 & 3,92 \\
\hline 7 & Kemudahan proses transaksi & 165 & 200 & 3,30 & 4,00 \\
\hline 8 & Keamanan transaksi & 164 & 200 & 3,28 & 4,00 \\
\hline 9 & Keamanan data pelanggan & 159 & 200 & 3,18 & 4,00 \\
\hline 10 & Kecepatan pengiriman Barang & 165 & 200 & 3,30 & 4,00 \\
\hline 11 & Ketepatan pengiriman barang & 156 & 200 & 3,12 & 4,00 \\
\hline 12 & Respon terhadap keluhan dan saran & 157 & 200 & 3,14 & 4,00 \\
\hline 13 & Kesesuaian produk yang di pesan & 163 & 200 & 3,26 & 4,00 \\
\hline & $\begin{array}{c}= \\
= \\
\text { Rata-rata X dan } \mathrm{Y}\end{array}$ & & & 3.18 & 3.98 \\
\hline
\end{tabular}

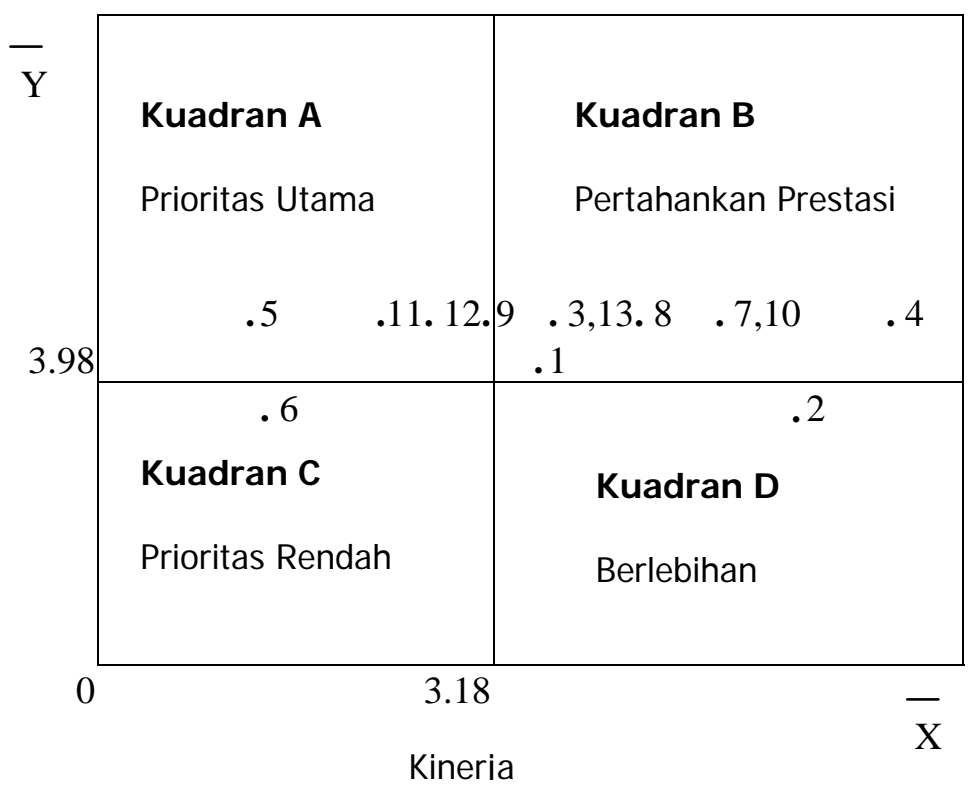

Gambar 3 Faktor yang Mempengaruhi Kepuasan Pelanggan Ojolali.com 
Dari hasil perhitungan Tabel 24 maka diperoleh titik-titik pada Diagram Kartesius (Gambar 3). Dalam Gambar 3 itu terlihat bahwa letak unsur pelaksana faktor atau atribut yang mempengaruhi kepuasan pelanggan Ojolali.com terbagi dalam empat bagian. Hasil pengukur faktor atau atribut kepuasan pelanggan itu berdasarkan tingkat Harapan dan Kinerjanya yang memungkinkan pihak perusahaan untuk dapat menitik beratkan usaha perbaikan untuk hal atau atribut yang benar-benar dianggap penting saja oleh pelanggan atau konsumen. Uraian diagram kartesius tersebut dapat dijelaskan seperti berikut.

1. Kuadran A

Faktor atau atribut kepuasan pelanggan Ojolali.com berada dalam kuadran itu dan pelaksanaannya perlu diprioritaskan oleh perusahaan. Hal itu karena keberadaan faktor itu yang dinilai sangat penting oleh pelanggan sedangkan tingkat pelaksanaannya masih belum memuaskan.

Faktor yang termasuk dalam kuadran A itu sebagai berikut.

- Harga produk yang kompetitif (=5).

- Keamanan data pelanggan (=9).

- Ketepatan pengiriman barang $(=11)$.

- $\quad$ Respon terhadap keluhan dan saran (=12).

2. Kuadran B

Menunjukan faktor atau atribut kepuasan pelanggan Ojolali.com berada dalam kuadran ini perlu dipertahankan karena pada umumnya tingkat pelaksanaannya telah sesuai dengan kepentingan dan harapan pelanggan. Oleh karena itu, dapat memuaskan pelanggan atau konsumen.

Faktor yang termasuk dalam kuadran B sebagai berikut.

- Tampilan website $(=1)$.

- Kelengkapan produk (=3).

- Kelengkapan informasi produk (=4).

- Kemudahan proses transaksi (=7).

- Keamanan transaksi (=8).

- Kecepatan pengiriman barang (=10).

- Kesesuaian produk yang dipesan (= 13).

3. Kuadran C

Menunjukkan bahwa faktor yang mempengaruhi kepuasan pelanggan Ojolali.com berada dalam kuadran itu dinilai masih kurang penting bagi pelanggan sedangkan kualitas pelaksanaannya biasa atau cukup saja.

Faktor yang ada dalam kuadran C sebagai berikut.

- $\quad$ Layanan Offline (=6) .

4. Kuadran D

Menunjukkan bahwa faktor yang mempengaruhi kepuasan pelanggan Ojolali.com berada dalam kuadran itu dinilai berlebihan dalam pelaksanaannya. Hal itu terutama karena pelanggan menganggap tidak terlalu penting terhadap adanya faktor tersebut. 
Akan tetapi, pelaksanaannya dilakukan dengan baik sekali oleh perusahaan sehingga dapat memuaskan, meskipun menjadi lebih mahal.

Faktor di dalam kuadran D sebagai berikut.

- Pengelompokan kategori produk (=19).

\section{Hasil Penelitian}

\section{Hasil Analisis Karakteristik Responden}

Dari hasil penelitian, diketahui bahwa 68\% pelanggan Ojolali.com berjenis kelamin pria dan 32\% adalah wanita yang mayoritas berusia 31 hingga 40 tahun (54\%). Dilihat dari daerah tempat tinggal, pelanggan Ojolali.com terbanyak berasal dari Jabotabek (48\%), Jawa hingga Bali menduduki peringkat kedua dengan 36\%, sedangkan luar Jawa hanya $12 \%$, dan 4\% dari luar negeri. Dari segi pekerjaan, karyawan swasta menduduki peringkat pertama dengan 36\%, disusul oleh mahasiswa dengan 24\%, dan professional $10 \%$. Wiraswasta hanya $12 \%$ dan sisanya $8 \%$ adalah pegawai negeri.

Berdasarkan hasil itu, dapat disimpulkan bahwa pelanggan Ojolali.com adalah pelanggan dengan tingkat ekonomi yang menengah ke atas. Hal itu dapat dilihat dari pengeluaran per bulannya dengan persentase terbesar (44\%), berasal dari pengeluaran di atas Rp5.000.000,00. Data selengkapnya dapat dilihat pada Tabel 25 berikut ini.

Tabel 25 Penelitian Karakteristik Responden

\begin{tabular}{crc}
\hline Karateristik Responden & Hasil (Jumlah Orang) & Persentase (\%) \\
\hline Jenis Kelamin & Pria (34) & 68 \\
& Wanita (16) & 32 \\
\hline Usia & $21-30$ tahun (20) & 40 \\
& $31-40$ tahun (27) & 54 \\
& $41-50$ tahun (3) & 6 \\
\hline Daerah Tempat tinggal & Jabotabek (24) & 48 \\
& Jawa - Bali (18) & 36 \\
& Luar Jawa (6) & 12 \\
& Luar Negeri (2) & 4 \\
\hline Jenis Pekerjaan & Mahasiswa (12) & 24 \\
& Wiraswasta (6) & 12 \\
& Pegawai Negeri (4) & 8 \\
& Karyawan Swasta(18) & 36 \\
& Profesional (10) & 20 \\
\hline Pengeluaran Per Bulan & 1.000 .000 - 2.000.000 (10) & 20 \\
& 2.000 .000 - 5.000.000 (18) & 36 \\
& $>5.000 .000(22)$ & 44 \\
\hline
\end{tabular}




\section{Hasil Analisis Perilaku Pembelian}

Dari penelitian perilaku pembelian terhadap 50 responden (pelanggan), dapat diketahui bahwa 56\% pelanggan mendapatkan informasi mengenai Ojolali.com dari iklan di internet. Bingkisan/hadiah merupakan produk yang paling dicari di Ojolali.com, berdasarkan hasil survei sebanyak 48\%. Data selengkapnya dapat dilihat pada Tabel 26.

Tabel 26 Hasil Penelitian Perilaku Pelanggan

\begin{tabular}{llc}
\hline Variabel & Hasil (Jumlah Orang) & Persentase (\%) \\
\hline Sumber Informasi & Iklan di Internet (28) & 56 \\
& Surat Kabar (5) & 10 \\
& Teman dan Keluarga (17) & 34 \\
\hline Produk yang Dicari & Buku - buku (14) & 28 \\
& Bingkisan/hadiah (24) & 48 \\
& Barang Elektronik (4) & 8 \\
& Lain - lain (8) & 16 \\
\hline Alasan Bebelanja & Keamanan Terjamin (28) & 56 \\
& Produknya Lengkap (12) & 24 \\
& Prosesnya cepat (6) & 12 \\
& Lain - lain (4) & 8 \\
\hline Frekuensi Pembelian & 1 - 5 kali (22) & 44 \\
& 6 - 10 kali (18) & 36 \\
& 11 - 15 kali (7) & 14 \\
& $>15$ kali (3) & 6 \\
\hline
\end{tabular}

Terjaminnya keamanan dalam bertransaksi (56\%) merupakan alasan responden melakukan perbelanjaan. Namun demikian, tingginya tingkat keamanan tidak diiringi dengan frekuensi pembelian. Hal itu dapat dilihat dari persentase terbesar responden melakukan pembeliaan hanya 1-5 kali saja (44\%). Dari hasil penelitian juga dapat diketahui bahwa 56\% pelanggan mendapatkan informasi mengenai Ojolali.com dari iklan di internet sedangkan bingkisan/hadiah merupakan produk yang paling dicari di Ojolali.com sebanyak 48\%. Terjaminnya keamanan dalam bertransaksi (56\%) merupakan alasan responden melakukan perbelanjaan. Namun demikian, tingginya tingkat keamanan tidak diiringi dengan frekuensi pembelian. Hal itu dapat dilihat dari persentase terbesar responden melakukan pembelian hanya $1-5$ kali saja, yaitu sebesar (44\%).

\section{Hasil Analisis Tingkat Kesesuaian Responden dan Diagram Kartesius}

Dari data yang didapatkan mengenai harapan dan pengalaman pelanggan, didapatkan hasil yang mencerminkan bahwa hampir semua faktor menghasilkan tingkat 
kesesuaian di atas 75\%. Secara rata-rata, tingkat kesesuaian reponden mencapai 79.82\%. Hal itu menunjukkan bahwa kinerja Ojolali.com sesuai dengan harapan pelanggan dan tingkat kesesuaiannya mencapai 79,82\%. Hasil selengkapnya dapat dilihat pada Tabel 27 berikut ini.

Tabel 27 Hasil Analisis Tingkat Kesesuaian Responden

\begin{tabular}{ccc}
\hline Faktor & $\%$ & Jumlah (orang) \\
\hline 1 & 80,9 & 40 \\
2 & 84,7 & 42 \\
3 & 82,7 & 41 \\
4 & 85,0 & 42 \\
5 & 68,5 & 34 \\
6 & 71,4 & 35 \\
7 & 82,5 & 41 \\
8 & 82,0 & 41 \\
9 & 79,5 & 39 \\
10 & 82,5 & 41 \\
11 & 78,0 & 39 \\
12 & 78,5 & 39 \\
13 & 81,5 & 40 \\
\hline Rata-rata & 79,82 & 39,5 \\
\hline
\end{tabular}

Tingkat kepuasan responden dibagi menjadi empat tingkatan berdasarkan skala Likert sebagai berikut.

1. Nilai rata-rata $1-25$, berarti sangat tidak puas.

2. Nilai rata-rata 26-50, berarti tidak puas.

3. Nilai rata-rata $51-75$, berarti puas.

4. Nilai rata-rata 76-100, berarti sangat puas.

Dari hasil penelitian, tingkat kesesuaian responden Ojolali.com berada pada tingkat 79,82\% maka dapat dikategorikan sangat puas.

\section{Analisis SWOT}

Suatu perusahaan harus mengetahui kondisi lingkungan tempat produk atau jasanya akan disebarkan. Oleh karena itu, perusahaan perlu mengetahui kekuatan (Strenght/S) dan kelemahan (Weaknesses/W) lingkungan dalamnya (Internal) dan juga mengkaji peluang (Opportunities/O) serta ancaman (Threats/T) dari eksternalnya. Kekuatan (Strength) yang dimiliki oleh Ojolali.com sebagai berikut.

1. Jumlah pelanggan yang banyak.

2. Produk yang beragam dan bermutu.

3. Sumber daya manusia yang terampil dibidangnya. 
4. Terpilih sebagai “Situs belanja buku pilihan” versi PC Media.

5. Sistem pembayaran yang sangat baik.

6. Kemudahan mengakses situs Ojolali.com.

7. Jasa kurir yang baik (pengiriman tepat waktu).

Kelemahan (Weakness) yang dimiliki oleh Ojolali.com, antara lain sebagai berikut.

1. Harga yang cenderung tinggi pada produk tertentu di banding pesaingnya.

2. Promosi yang kurang.

3. Jumlah pembeli terhadap pengunjung relatif lebih kecil.

4. Kurangnya kantor perwakilan di daerah.

5. Segmen pasar yang tidak menjangkau seluruh lapisan masyarakat.

Kesempatan (Opportunity) yang dimiliki oleh Ojolali.com, sebagai berikut.

1. Pertumbuhan penduduk.

2. Daya konsumsi yang cukup tinggi.

3. Pola gaya hidup konsumen yang berubah-ubah.

4. Prospek e-Commerce.

5. Banyaknya investor yang tertarik dalam bisnis ini.

Ancaman (Threat) juga dimiliki oleh Ojolali.com, antara lain sebagai berikut.

1. AFTA (Asean Free Trade Area).

2. Infrastruktur, mahalnya biaya telepon dan internet.

3. Budaya, masyarakat lebih suka bebelanja langsung, seperti di mal dan pasar.

4. Pengetahuan tentang e-Commerce yang masih kurang di Indonesia.

5. Kondisi perekonomian yang tidak menentu.

6. Internet user, belum memasyarakatnya e-Commerce di Indonesia.

7. Banyak bermunculan Superstore dimana-mana.

Tabel 28 Matriks EFAS

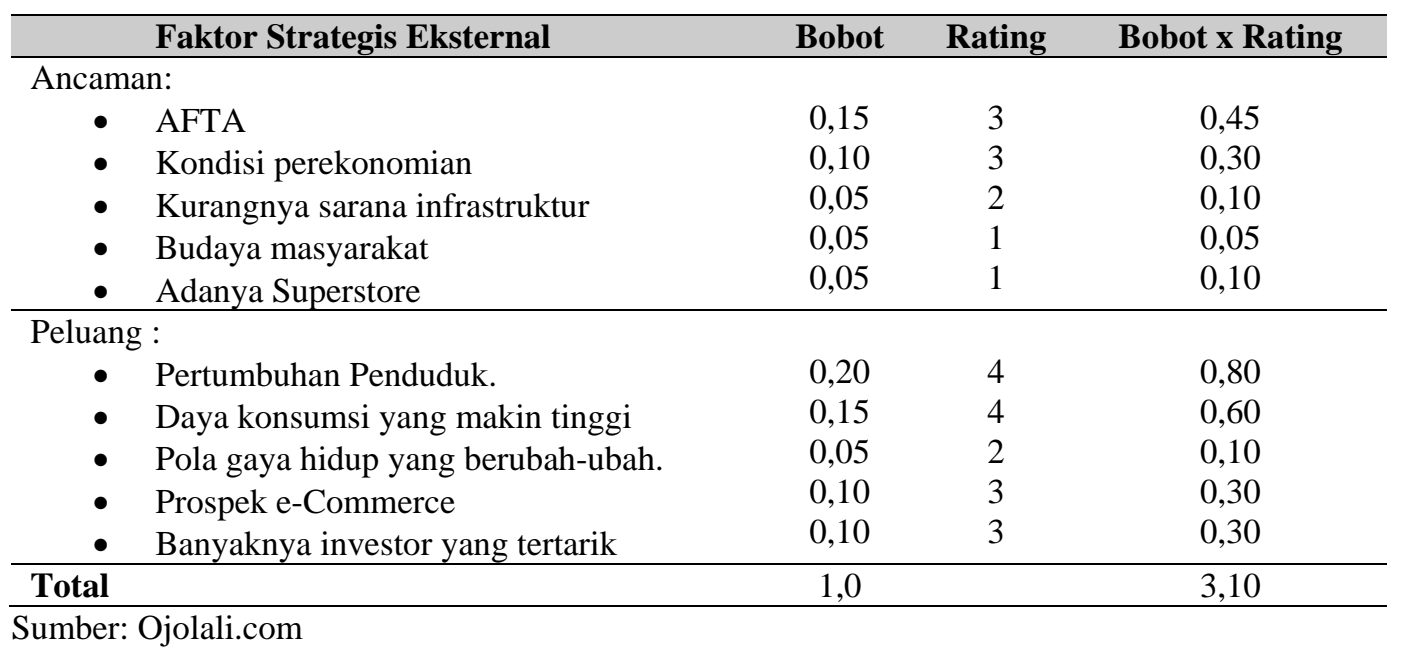


Tabel 29 Matriks IFAS

\begin{tabular}{|c|c|c|c|}
\hline Faktor Strategis Internal & Bobot & Rating & Bobot x Rating \\
\hline \begin{tabular}{ll}
\multicolumn{1}{c}{ Kekuatan: } \\
- & Produk-produk yang beragam dan bermutu \\
- & Sumber Daya Manusia yang terampil di \\
- & bidangnya \\
- & perpilih sebagai “Situs belanja buku \\
- $\quad$ Sistem pembayaran yang sangat baik \\
- Jumlah pelanggan yang banyak
\end{tabular} & $\begin{array}{l}0,20 \\
0,05 \\
0,10 \\
0,10 \\
0,15\end{array}$ & $\begin{array}{l}3 \\
4\end{array}$ & $\begin{array}{l}0,05 \\
0,30\end{array}$ \\
\hline \begin{tabular}{ll}
\multicolumn{1}{c}{ Kelemahan : } \\
- & Promosi yang kurang \\
- & Harga yang lebih tinggi dari pesaing \\
- & Penyediaan barang berada di mitra kerja \\
- & Jumlah pembeli relatif kecil dibandingkan \\
- & $\begin{array}{l}\text { Kurang ada kantor perwakilan di daerah- } \\
\text { daerah }\end{array}$ \\
\end{tabular} & $\begin{array}{l}0,15 \\
0,10 \\
0,05 \\
0,05\end{array}$ & $\begin{array}{l}4 \\
2 \\
1\end{array}$ & $\begin{array}{l}0,60 \\
0,20 \\
0,05 \\
0,05\end{array}$ \\
\hline
\end{tabular}

Sumber: Ojolali.com

\section{Hasil Analisis SWOT}

Berdasarkan analisis, strategi Ojolali.com berada pada posisi WO, yaitu menciptakan strategi dengan meminimalkan kelemahan untuk memanfaatkan peluang. Posisi Ojolali.com itu dapat dilihat pada Gambar 4 berikut ini.

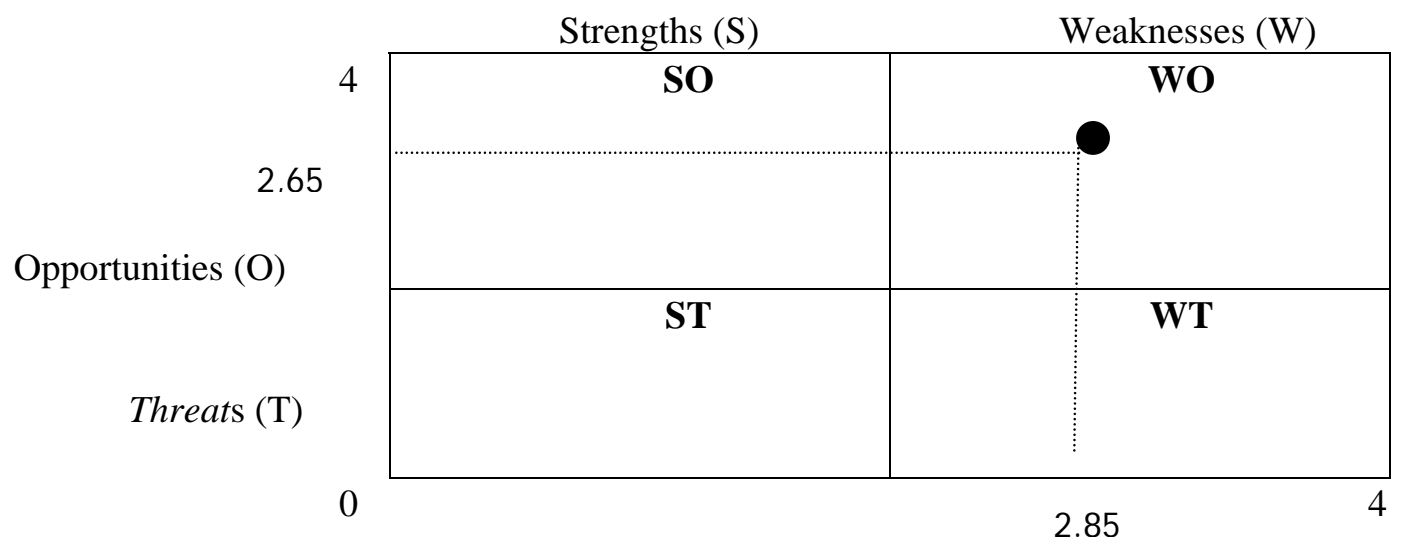

Gambar 4 Letak Strategi Ojolali.com 


\section{Matriks SWOT}

Berdasarkan penelitian, posisi Ojolali.com berada pada strategi WO, yaitu strategi yang diterapkan berdasarkan pemanfaatan peluang yang ada dengan cara menimalkan kelemahan yang ada. Langkah yang dapat diambil oleh Ojolali.com dengan strategi WO adalah dengan cara menghimpun dana kemudian melakukan promosi besarbesaran, serta melakukan strategi harga guna mengatasi persaingan harga yang kompetitif. Untuk lebih jelasnya, strategi tersebut dapat dilihat pada Tabel 30 berikut ini.

Tabel 30 Matriks SWOT

\begin{tabular}{|c|c|c|}
\hline EFAS & $\begin{array}{ll}\text { Strength }(\mathrm{S}) \\
\text { - } & \text { Pelanggan yang banyak } \\
\text { - } & \text { Produk yang beragam } \\
\text { - } & \text { SDM yang terampil } \\
\text { - } & \text { Peningkatan penjualan } \\
\text { - } & \text { Situs terbaik } \\
\text { - } & \text { Sistem pembayaran }\end{array}$ & $\begin{array}{l}\text { Weakness (W) } \\
\text { - Promosi yang kurang } \\
\text { - Harga yang tinggi } \\
\text { - Penyediaan barang berada di } \\
\text { mitra kerja } \\
\text { - Kurangnya kantor } \\
\text { perwakilan di daerah. } \\
\text { - Segmentasi pasar tidak ke } \\
\text { seluruh lapisan }\end{array}$ \\
\hline $\begin{array}{l}\text { Opportunity }(\mathrm{O}) \\
\text { - Pertumbuhan penduduk } \\
\text { - Daya konsumsi } \\
\text { - Pola gaya hidup } \\
\text { - Prospek B2B } \\
\text { - Investor yang tertarik }\end{array}$ & $\begin{array}{l}\text { Strategi SO } \\
\text { - Optimalisasi SDM } \\
\text { - Mempertahankan Citra Situs } \\
\text { - Mencari pelanggan sebanyak } \\
\text { mungkin } \\
\text { - Penambahan produk }\end{array}$ & $\begin{array}{l}\text { Strategi WO } \\
\text { - } \quad \text { Melakukan promosi yang } \\
\text { lebih aktif agar lebih dikenal } \\
\text { - Menerapkan strategi harga } \\
\text { - Mencari pemasok lain untuk } \\
\text { mengatasi masalah harga } \\
\text { agar lebih kompetitif }\end{array}$ \\
\hline $\begin{array}{l}\text { Threats }(\mathrm{T}) \\
\text { - AFTA } \\
\text { - Infrastruktur } \\
\text { - Budaya } \\
\text { - Pengetahuan/Knowledge } \\
\text { - Internet user }\end{array}$ & $\begin{array}{l}\text { Strategi ST } \\
\text { - Meningkatkan mutu barang } \\
\text { serta pelayanan yang lebih } \\
\text { baik. } \\
\text { - } \text { Penjelasan teknis melalui } \\
\text { social education untuk } \\
\text { masyarakat } \\
\text { - Mengoptimalkan penggunaan } \\
\text { teknologi internet }\end{array}$ & $\begin{array}{l}\text { Strategi WT } \\
\text { - Menerapkan strategi bisnis } \\
\text { baru yang lebih efisien dan } \\
\text { efektif } \\
\text { - Efektifitas pengunaan } \\
\text { internet } \\
\text { - Peningkatan pelayanan } \\
\text { kepada pelanggan }\end{array}$ \\
\hline
\end{tabular}


cara berikut.

Penerapan strategi SWOT dalam Ojolali.com, antara lain dapat dilakukan dengan

1. Strategi SO

- Mengoptimalkan sumber daya manusia, misalkan dengan peningkatan standar karyawan pada saat penerimaan karyawan baru, contoh Minimal D3 menjadi Minimal S1.

- Mencari investor lain yang bertujuan untuk menambah modal perusahaan sehingga dapat menghadirkan produk yang lebih lengkap dan juga mencari pemasok lain agar didapat barang yang beraneka ragam.

- Dengan adanya penghargaan sebagai situs terbaik pilihan PC Media maka perlu bagi Ojolali.com untuk mempertahankan penghargaan tersebut.

\section{Strategi WO}

- Strategi yang dapat dilakukan Ojolali.com antara lain dengan melakukan kerja sama dengan situs lain agar saling me-link antar situs atau dengan menempatkan iklan di situs lain.

- Strategi lainya adalah dengan cara melakukan strategi harga, yaitu dengan cara mencari supplier lain yang dapat dapat lebih menekan harga sehingga didapat harga yang lebih murah.

- Penekanan harga seefektif mungkin dari harga yang didapat sehingga dapat bersaingan dengan situs lain dan juga pada bisnis offline (konvensional).

3. Strategi ST

- Dalam pengontrolan mutu barang, dapat dilakukan dengan cara menyeleksi barang dari supplier agar barang yang akan dipasarkan oleh perusahaan dapat berkualitas.

- Penyuluhan dan pengenalan internet dapat membantu mengubah kebiasaan masyarakat dalam pengunaan internet sehingga dapat menambah prospek bagi perusahaan.

- Untuk daya saing dengan bisnis konvensional, kemudahan dalam bertransaksi harus lebih ditingkatkan, contohnya dengan kerja sama dengan bank swasta yang lebih banyak sehingga dapat memudahkan dalam pengiriman dana.

4. Strategi WT

- Lebih mengefektifkan promosi, contohnya dalam pemasangan iklan. Iklan Ojolali akan lebih efektif apabila dipasang di majalah komputer daripada dipasang di majalah remaja.

- Kepuasan pelanggan dapat ditingkatkan dengan cara meningkatkan pelayanan yang telah ada, contohnya dalam ketepatan pengiriman barang, apabila jasa kurir yang dipakai dirasa tidak dapat memenuhi pesanan dengan tepat maka perlu dilakukan pengantian jasa kurir.

- Perlunya dilakukan pencarian investor baru sehingga dapat meningkatkan modal perusahaan. Hal tersebut dilakukan agar dapat membuat kantor perwakilan guna melayani pemesanan maupun keluhan dari konsumen. 


\section{PENUTUP}

\section{Simpulan}

Berdasarkan penelitian yang telah dilakukan, diperoleh simpulan sebagai berikut.

1. Mayoritas pelanggan Ojolali.com adalah pria (68\%), berusia 31-40 tahun (54\%). Mayoritas mereka tinggal di Indonesia, khususnya Jabotabek (48\%). Pelanggan Ojolali dapat dikatakan kebanyakan dari kalangan menengah ke atas karena mayoritas pengeluaran mereka di atas 2 juta rupiah perbulan (80\%).

2. Umumnya, pelanggan Ojolali.com mengenal Ojolali dari iklan di internet (56\%), kebanyakan produk yang mereka cari adalah hadiah/bingkisan (48\%). Terjaminnya keamanan merupakan faktor pendorong terbesar para pelanggan melakukan transaksi di Ojolali (56\%) yang kebanyakan telah melakukan transaksi sebanyak (44\%).

3. Dari 13 faktor yang diberikan oleh Ojolali.com, ada empat faktor yang harus menjadi prioritas utama, yaitu harga yang kompetitif, keamanan data pelanggan, ketepatan pengiriman barang, dan respons terhadap keluhan dan saran. Hal itu karena pelanggan mengangap faktor tersebut sangat penting kemudian ada tujuh faktor, yaitu tampilan website, kelengkapan produk, kelengkapan informasi produk, kemudahan proses transaksi, keamanan transaksi, kecepatan pengiriman barang, kesesuaian produk yang dipesan yang perlu dipertahankan agar dapat bersaing dengan perusahaan sejenis. Terdapat 1 faktor yang dianggap berlebihan pelayanannya, yaitu pengelompokan kategori produk dan 1 faktor lagi dianggap tidak begitu penting sehingga mereka menggangap tidak perlu diutamakan pelaksanaannya. Dari hasil analisis tingkat kesesuaian antara kinerja yang diberikan Ojolali.com dengan harapan pelanggan, tingkat kesesuaiannya mencapai $79,82 \%$. Hal itu dapat dianggap bahwa tingkat kepuasan pelanggan Ojolali.com sebesar 79,82\% (puas).

4. Dari hasil analisis penerapan strategi dengan metode SWOT, diketahui Ojolali.com berada dalam penerapan strategi $\mathrm{W}$ dan Ojolali.com harus menciptakan strategi yang meminimalkan kelemahan untuk memanfaatkan peluang, seperti melakukan promosi yang lebih aktif dan melakukan strategi harga.

\section{Saran}

Saran yang dapat diberikan kepada Ojolali.com sebagai berikut:

1. Ojolali.com sebaiknya menerapkan suatu konsep yang orientasi perusahaannya dipusatkan kepada pelanggan sehingga apabila dikemudian hari ingin mengambil keputusan ataupun ingin membuat kebijakan, selalu bertolak pada kepuasan pelanggan.

2. Mayoritas pelanggan Ojolali.com dapat dikategorikan sebagai masyarakat yang tingkat ekonominya berada pada tingkat menengah ke atas. Hal itu dilihat dari tingkat 
pengeluaran mereka per bulan. Untuk kalangan masyarakat seperti itu, mereka lebih mengutamakan pelayanan sedangkan harga produk di nomor duakan.

\section{DAFTAR PUSTAKA}

Anonymous. Apa dan Bagaimana E-Commerce. 2002. Semarang: Wahana Komputer dan Yogyakarta: Andi.

Hanson, Ward. 2000. Pemasaran Internet. Jakarta: Salemba Emban Patria.

Indrajit, R. 2001. Koleksi Tulisan dan Pemikiran E-Commerce: Kiat dan Strategi Bisnis di Dunia Maya. Jakarta: Elex Media Komputindo.

Indriantoro, Nur dan Bambang Supomo. 1999. Metodologi Penelitian Bisnis. Yogyakarta: BPFE.

Oetomo, Budi. 2001. Perspektif E-Business: Tinjauan Teknis, Manajerial, dan Strategi. Yogyakarta: Andi.

Ojolali. 2003. http://www.Ojolali.com.

Rangkuti, Freddy. 2003. Analisis SWOT: Teknik Membedah Kasus Bisnis. Jakarta: Gramedia Pustaka Utama.

Robinson, R. dan John Pearce. 1998. Manajemen Strategik. Jakarta: Binarupa Aksara.

Sukirno, Sadono. 2002. Pengantar Teori Mikroekonomi. Jakarta: RajaGrafindo Persada.

Supranto, J. 2001. Pengukuran Tingkat Kepuasan Pelanggan untuk Menaikkan Pangsa Pasar. Jakarta: Rineka Cipta.

Tjiptono, Fandi. 2001. Strategi Pemasaran. Yogyakarta: Andi

Wahyudi, Aang dan Purbo O.W. 2001. Mengenal E-Commerce. Jakarta: Elex Media Komputindo. 